\title{
Prevalence of Educational Malpractice among University Students as Perceived by Lecturers of Delta State University, Abraka
}

\author{
Anna Onoyase ${ }^{1}$, Ph.D. \\ ${ }^{1}$ Department of Guidance and Counselling, Delta State University, Abraka, Nigeria \\ Correspondence: Anna Onoyase, Ph.D., Department of Guidance and Counselling, Delta State University, Abraka, \\ Nigeria
}

Received: July 13, 2018

Accepted: August 17, 2018

Online Published: August 22, 2018

doi:10.5430/ijhe.v7n4p187

URL: https://doi.org/10.5430/ijhe.v7n4p187

\begin{abstract}
The study examined the prevalence of educational malpractice among University students as perceived by lecturers of Delta State University, Abraka. Three research questions were raised to guide the study. The study is a descriptive survey research. The purposive random sampling technique was used to select a sample of 92 lecturers for the study. The instrument for this study is the questionnaire. The instrument has face and content validity through expert judgement and instrumentation. The Cronbach alpha procedure was used to assess the internal consistency of the items. The value obtained was .73 . The results revealed that there is a high prevalence of educational malpractice among undergraduates of Delta State University, Abraka. The findings also revealed that there is no significant difference between lecturers in their perception of the prevalence of educational malpractice among students. Lastly, the result showed that the status of lecturers has no impact on their perception of the prevalence of educational malpractice among students. Implications for counselling practice and education were discussed.
\end{abstract}

Keywords: educational malpractice, students, lecturers

\section{Introduction}

Education globally is supposed to be an on-going process which commences at birth and ends at death; and it is one of the greatest force that may be employed by any country to bring transformation to the populace. Though, still a developing country, Nigeria like other nations of the world appears to have realized that education is a major instrument for promoting national development which could be social, political, economic and technological. The emergence of globalization may have further increased the awareness of different countries (including Nigeria) of the great benefit of education in transforming the lives of learners, so as to be useful to themselves and the society. Still on the importance of education, Machebe and Ifelunni (2014) opined that education has been found to be a key index of development and that, it not only provides knowledge and skills but also inculcates values, training of instincts and fostering of the right attitude. Right attitude has to do with compliance to rules and regulations and in this study, it involves students' adherence to academic regulations in universities. Akaranga and Ongong (2013) also observed that education is a necessary process through which young adults are equipped to lead productive lives according to their talents and interest. Based on the aforementioned benefits to be derived from education, Nigeria is striving to develop her manpower so that they will contribute their quota to development in different areas of life. This is being implemented by investing in the education of its citizens generally and university education in particular.

Undoubtedly, universities otherwise known as "Ivory Towers" are expected to play vital roles in shaping the behaviours of students and these expectations are in line with the major aims of tertiary education as stipulated in the National Policy of Education (2016). They include:

a. The acquisition, development and inculcation of proper value orientation of survival of the individual and society.

b. The development of the intellectual capacities of individuals to understand and appreciate their environments.

c. The acquisition of both physical and intellectual skills, which will enable individuals to develop into useful members.

Additionally, there are academic regulations guiding registration, workload of students and examination in various Nigerian universities. As stated in the Faculty of Education, Students' Information Handbook, (2016), students are 
expected to register for courses within 3 weeks of the commencement of the first semester of every session, they are only eligible to take examination when they (students) have attended lectures $75 \%$ contact hours. But when undergraduate students fail to register their courses at the right time or don't register at all, when students absent themselves from lectures, they are involved in educational malpractice.

The purpose of this paper is to investigate the prevalence of educational malpractice among university students. Educational Malpractice can be defined as Students' failure to observe academic regulations in universities. The study of Akpochafo and Asiyai (2015), revealed that there are various types of Educational Malpractice in tertiary institutions and these are examination malpractice, admission malpractice, administration malpractice, teaching malpractice/ learning malpractice and research malpractice. But this researcher has added registration malpractice to the above list based on her experience. This study is restricted to learning malpractice, examination malpractice and registration malpractice. Learning malpractice has to do with students' negative attitude towards learning such as absenteeism, inattentiveness in class, failure to do assignments and poor study habits. Examination malpractice involves students, unethical behavior during examination which include impersonation, giraffing, bringing prepared materials to the hall for use and exchange of answer scripts. While registration malpractice embraces students' disobedience in registering their courses within the stipulated period and outright failure to register their courses.

From observation as a lecturer in Delta State University, undergraduate students are no longer interested in learning and thus resort to examination malpractice, do not register their courses at the right time, deliberately absent themselves from lectures, fail to do their assignments and these graduate without being able to defend the certificates they have acquired. Again, those who have been employed don't seem to possess the required skills to perform to their optimal level and thus there is underemployment and manpower wastage. Buttressing this point, Ebenuwa-okoh (2009) noted that some of the consequences of educational malpractice include emptiness, lack of self-confidence and that these result to wastage of human resources and national underdevelopment.

Akpochafo (2007) opined that some students of tertiary institutions do not make $75 \%$ attendance at lectures to qualify them to write examinations; continuing, she reiterated that absenteeism from lecture, lateness to classes, engaging in different forms of examination malpractice, offering money, sex and other enticement in exchange for higher grades are common practices in universities. Educational malpractice in universities seem to be on the increase and undergraduate students regard them as "normal practices".

Still on these unethical behaviours, Onoyase (2014) observed some deviant behaviour among undergraduates of Delta State University, Abraka and these include deliberate lateness to lectures, absenteeism, inattentiveness in class, paying colleagues to do assignments for them and unwillingness of students to acquire textbooks and other reference materials needed for their study. These behaviours, if not checked might truncate the actualization of the objectives of tertiary education and the specific goals of individual university. Lamenting the prevalence of malpractice in higher institutions of learning, Aluede (2015) pointed out that students resort to "blocking" that is, using money to get high and unmerited marks from lecturers in order to enhance their final grade point.

Also in the views of Bruno and Obidigbo (2012), the most common forms of examination malpractice among undergraduates include the following: coming into the examination hall with small pieces of paper full of tiny written materials, giraffing or spying on their neighbours' work, whispering answer, exchange of answers scripts, impersonation and use of handsets, This is one of the forms of educational malpractice that is rampant in tertiary institutions, In a study conducted by Onah (2010) at the College of Education, Jalingo, 150 cases of examination malpractice between 2002 and 2007 were reviewed and the author identified 125 expulsion cases out of the sample size. This research revealed the high level of examination malpractice in the institution used for the research.

\subsection{Statement of the Problem}

In the 70s and 80s in Nigeria, there seemed to be much discipline in higher institutions of learning, specifically universities. There were few universities and gaining admission into them was comparable to obtaining a Visa to travel abroad. The undergraduates of old took their studies, seriously because the society placed much emphasis on hardwork and they graduated with good results. As a matter of fact, the incidence of educational malpractice among these students was minimal because they felt that such practice could bring shame to them and their families as well. Presently, some university students are no longer interested in learning but want to acquire certificates at all cost. Thus, they indulge in certain behaviours (which can he labeled as educational malpractice) and these include "blocking" (that is, using money to get high and unmerited marks from lecturers), indulging in examination malpractice in order to pass examination, paying colleagues to do assignments for them, absenteeism and unwillingness to acquire textbooks and other reference materials needed. The problem of this study therefore is to 
investigate the prevalence of educational malpractice among university students as perceived by lecturers of Delta State University, Abraka.

\subsection{Research Questions}

Three research questions were raised to guide the study:

i. What are the prevalent educational malpractices among students as perceived by lecturers of Delta State University, Abraka?

2. What are the prevalent educational malpractices among university students as perceived by lecturers based on gender?

3. What are the prevalent educational practices among university students as perceived by lecturers based on status?

\subsection{Purpose of the Study}

The purpose of this paper was to investigate the prevalence of educational malpractice among university students as perceived by lecturers of Delta State University, Abraka and then provide counselling so as to minimize such incidence

\section{Methods}

This study is a descriptive survey research. The target population are lecturers in Delta State University, Abraka. Purposive random sampling technique was used to select a sample of 92 lecturers for this study. The instrument for this study is the questionnaire titled "prevalence of educational malpractice among university students as perceived by lecturers of Delta State University". The instrument for this study is made up of two sections. Section A elicits information on bio-data of respondents: gender, level of study, type of family, status and years of experience. While Section B examines various forms of malpractice practiced by students such as failure to register courses at the right time, not doing their assignments, refusal to take lectures among other truant behaviour patterns. The instrument has face and content validity through expert judgement and instrumentation. Cronbach alpha procedure was used to assess the internal consistency of the items. 0.73 was the $r$ value obtained. The acceptance point for the item is 2.50 . 2.50 was (arbitrarily chosen as the bench mark because it is above the average. The mean values of 2.50 and above were regarded as being high and, denote prevalence of educational malpractice. The grand mean used in this study denotes the average mean of the respondents. The significance is that it indicates the average responses of the subjects based on the items tested. The data collected was analyzed using mean rating and standard deviation for the research questions at 0.05 level of significance.

\section{Results}

\subsection{Research Question}

What are the prevalent educational malpractices among university students as perceived by lecturers? 
Table 1. Mean Rating and standard Deviation of Educational Malpractice among Students as Perceived by Lecturers

\begin{tabular}{|c|c|c|c|}
\hline $\mathbf{S} / \mathbf{N}$ & Items & Means & SD \\
\hline 1 & $\begin{array}{l}\text { Every session, some students don't register their courses (both manually and online) on } \\
\text { time. }\end{array}$ & 3.71 & .63 \\
\hline 2 & Most times, some students do not complete their registration. & 3.24 & 66 \\
\hline 3 & $\begin{array}{l}\text { A good number of students do not see the need to attend lectures, so they stay away } \\
\text { from classes. }\end{array}$ & 3.11 & 66 \\
\hline 4 & $\begin{array}{l}\text { Some students find it difficult to do assignment, so they pay other students to assist } \\
\text { them }\end{array}$ & 3.24 & .70 \\
\hline 5 & $\begin{array}{l}\text { One trick some students use in obtaining scores is to apply for missing scores for } \\
\text { courses they have failed }\end{array}$ & 3.05 & 69 \\
\hline 6 & Some students who miss examination deliberately apply for missing scores & 2.90 & .97 \\
\hline 7 & $\begin{array}{l}\text { Deliberate attempt to bribe course advisers to change scores is a common practice } \\
\text { among students in Nigerian universities }\end{array}$ & 2.65 & .90 \\
\hline 8 & $\begin{array}{l}\text { Many students feel that it is too rigorous to write project, thus, they "hire" people to } \\
\text { write for them }\end{array}$ & 3.01 & .55 \\
\hline 9 & $\begin{array}{l}\text { Some students don't prepare for examination, so they pay other students to write for } \\
\text { them }\end{array}$ & 3.02 & .54 \\
\hline 10 & $\begin{array}{l}\text { Another method students use to obtain 'good grades' is to sit close to intelligent } \\
\text { students in the examination hall }\end{array}$ & 3.26 & .58 \\
\hline 11 & $\begin{array}{l}\text { Some students bring prepared materials to the examination hall and use them when the } \\
\text { invigilators are not watching }\end{array}$ & 3.37 & .86 \\
\hline 12 & $\begin{array}{l}\text { The practice whereby some students bribe lecturers to score high mark is common in } \\
\text { Nigerian universities }\end{array}$ & 2.26 & .50 \\
\hline 13 & Some students are more interested in certificates than learning & 3.52 & .83 \\
\hline 14 & Some students register with identify card (ID) of other students & 2.76 & .84 \\
\hline \multirow[t]{2}{*}{15} & Some students use "public relation" in passing examination & 2.77 & .40 \\
\hline & Grand Mean & 3.06 & \\
\hline
\end{tabular}

Table 1 shows that the grand mean score of the lecturers on the prevalence of educational malpractice among undergraduates is 3.06 which is above the bench mark of 2.50. The grand mean score of 3.06 represents the average responses of lecturers on the prevalent educational malpractice among students in Delta State University, Abraka. This shows that the prevalence of educational malpractice by undergraduates is high in Delta State University, Abraka.

\section{Research Question 2}

What are the prevalent educational malpractices among University students as perceived by lecturers based on gender? In order to answer this question, mean values and standard deviation of items 1-15 are presented in table 2 below: 
Table 2. Mean Ratings and Standard Deviation of prevalence of Educational Malpractice among Students as perceived by Lecturers based on gender

\begin{tabular}{|c|c|c|c|c|c|}
\hline \multirow[b]{2}{*}{$\mathbf{S} / \mathbf{N}$} & \multirow[b]{2}{*}{ Items } & \multicolumn{2}{|l|}{ MALE } & \multicolumn{2}{|c|}{ FEMALE } \\
\hline & & Means & SD & Means & SD \\
\hline 1 & $\begin{array}{l}\text { Every session, some students don't register their courses (both } \\
\text { manually and online) on time }\end{array}$ & 3.10 & .62 & 3.24 & .64 \\
\hline 2 & Most times some students do not complete their registration & 3.30 & 66 & 3.17 & .65 \\
\hline 3 & $\begin{array}{l}\text { A good number of students do not see the need to attend } \\
\text { lecturers, so they stay away from classes most times. }\end{array}$ & 3.04 & .71 & 3.17 & 60 \\
\hline 4 & $\begin{array}{l}\text { Some students find it difficult to do assignments, so they pay } \\
\text { other students to assist them }\end{array}$ & 3.34 & .71 & 3.13 & 69 \\
\hline 5 & $\begin{array}{l}\text { One trick some students use in obtaining scores is to apply for } \\
\text { missing scores for courses they have failed }\end{array}$ & 3.00 & .76 & 3.10 & 62 \\
\hline 6 & $\begin{array}{l}\text { Some students who miss examination deliberately apply for } \\
\text { missing scores }\end{array}$ & 2.84 & 1.18 & 2.96 & .86 \\
\hline 7 & $\begin{array}{l}\text { Deliberate attempt to bribe course advisers to change scores is a } \\
\text { common practice among students in Nigerian universities }\end{array}$ & 2.20 & 1.17 & 3.10 & .77 \\
\hline 8 & $\begin{array}{l}\text { Many students feel that it is too rigorous to write project, thus, } \\
\text { they "hire" people to write for them }\end{array}$ & 2.80 & 1.18 & 3.24 & .62 \\
\hline 9 & $\begin{array}{l}\text { Some students don't prepare for examination, so they pay other } \\
\text { students to write for them }\end{array}$ & 2.90 & .24 & 3.13 & .35 \\
\hline 10 & $\begin{array}{l}\text { Another method students use to obtain 'good grades' is to sit } \\
\text { close to intelligent students in the examination hall }\end{array}$ & 3.41 & .57 & 3.10 & .50 \\
\hline 11 & $\begin{array}{l}\text { Some students bring prepared materials to the examination hall } \\
\text { and use them when the invigilators are not watching }\end{array}$ & 3.50 & .52 & 3.24 & .64 \\
\hline 12 & $\begin{array}{l}\text { The practice whereby some students bribe lecturers to score high } \\
\text { mark is common in Nigerian universities }\end{array}$ & 2.62 & .92 & 2.93 & .80 \\
\hline 13 & Some students are more interested in certificates than learning & 3.66 & .50 & 3.38 & .50 \\
\hline 14 & Some students register with identify card (ID) of other students & 2.52 & 1.01 & 3.00 & .65 \\
\hline \multirow[t]{2}{*}{15} & Some students use "public relation" in passing examination & 2.61 & .92 & 2.93 & .75 \\
\hline & Grand Mean & 3.00 & & 3.12 & \\
\hline
\end{tabular}

From the table 2, the mean values of all the items (except number 7) were above the bench mark of 2.50 for male lecturers which are the level of acceptance. While for female lecturers, the mean scores for all the items are above the bench mark of 2.50. The grand mean scores of 3.00 for males and 3.12 for females denote the average means of the lecturers' responses on the prevalence of Educational Malpractice among Students in Delta State University, Abraka. This implies that all the lecturers irrespective of gender have acknowledged that their students are involved in educational malpractice.

\section{Research Question 3}

What are the prevalent educational malpractice among university students as perceived by lecturers based on status? 
Table 3. Mean Ratings and Standard Deviation of Prevalence of Educational Malpractice among Students as perceived by Lecturers based on status

\begin{tabular}{|c|c|c|c|c|c|}
\hline \multirow{2}{*}{$\mathbf{S} / \mathbf{N}$} & \multirow{2}{*}{ Items } & \multicolumn{2}{|c|}{$\begin{array}{l}\text { Assistant lecturer } \\
\text { to lecturer I }\end{array}$} & \multicolumn{2}{|c|}{$\begin{array}{l}\text { Senior lecturers } \\
\text { to professors }\end{array}$} \\
\hline & & Means & SD & Means & SD \\
\hline 1 & $\begin{array}{l}\text { Every session, some students don't register their courses (both } \\
\text { manually and online) on time }\end{array}$ & 3.15 & .55 & 3.18 & .85 \\
\hline 2 & Most times some students do not complete their registration & 3.28 & .67 & 3.23 & .61 \\
\hline 3 & $\begin{array}{l}\text { A good number of students do not see the need to attend } \\
\text { lecturers, so they stay away from classes most times. }\end{array}$ & 3.10 & .60 & 3.50 & .95 \\
\hline 4 & $\begin{array}{l}\text { Some students find it difficult to do assignments, so they pay } \\
\text { other students to assist them }\end{array}$ & 3.34 & .65 & 3.10 & .85 \\
\hline 5 & $\begin{array}{l}\text { One trick some students use in obtaining scores is to apply for } \\
\text { missing scores for courses they have failed }\end{array}$ & 3.08 & .63 & 2.86 & .99 \\
\hline 6 & $\begin{array}{l}\text { Some students who miss examination deliberately apply for } \\
\text { missing scores }\end{array}$ & 2.94 & 1.1 & 2.63 & .90 \\
\hline 7 & $\begin{array}{l}\text { Deliberate attempt to bribe course advisers to change scores is a } \\
\text { common practice among students in Nigerian universities }\end{array}$ & 2.44 & 1.1 & 2.55 & 1.01 \\
\hline 8 & $\begin{array}{l}\text { Many students feel that it is too rigorous to write project, thus, } \\
\text { they "hire" people to write for them }\end{array}$ & 2.94 & 1.10 & 3.00 & .97 \\
\hline 9 & $\begin{array}{l}\text { Some students don't prepare for examination, so they pay other } \\
\text { students to write for them }\end{array}$ & 3.01 & .60 & 2.86 & .83 \\
\hline 10 & $\begin{array}{l}\text { Another method students use to obtain 'good grades' is to sit } \\
\text { close to intelligent students in the examination hall }\end{array}$ & 3.35 & .53 & 3.23 & .63 \\
\hline 11 & $\begin{array}{l}\text { Some students bring prepared materials to the examination hall } \\
\text { and use them when the invigilators are not watching }\end{array}$ & 3.40 & .56 & 3.34 & .58 \\
\hline 12 & $\begin{array}{l}\text { The practice whereby some students bribe lecturers to score high } \\
\text { mark is common in Nigerian universities }\end{array}$ & 2.70 & .94 & 2.77 & .75 \\
\hline 13 & Some students are more interested in certificates than learning & 3.58 & .50 & 3.60 & .59 \\
\hline 14 & Some students register with identify card (ID) of other students & 2.68 & 1.06 & 2.59 & .80 \\
\hline \multirow[t]{2}{*}{15} & Some students use "public relation" in passing examination & 2.70 & .93 & 2.77 & .70 \\
\hline & Grand Mean & 3.04 & & 3.03 & \\
\hline
\end{tabular}

Table 3 shows that the grand mean scores of junior lecturers (Assistant lecturers to lecturer 1) is 3.04 while for senior lecturers (Senior lecturers to professors) is 3.03. These are the average responses of all the lecturers (junior and senior alike) on the prevalence of educational malpractice in Delta State University, Abraka. There is little or no difference between lecturers' perception on the prevalence of educational malpractice among students based on status. The mean score for lecturers irrespective of status is above 2.50. This implies that they have identified educational malpractice as prevalent among students.

\section{Discussion of Findings}

The first finding has indicated that the grand mean score of the lecturers on the prevalence of educational malpractice among undergraduates is 3.06, which is above the bench mark of 2.50 . This implies that there is high prevalence of educational malpractice among students in Delta State University, Abraka. The reason one can adduce for this finding is wrong societal values which students have imbibed, values that de-emphasize hard work, honesty and diligence. This finding corroborates the view of Akpochafo (2007) who noted that some students of tertiary institutions do not make $75 \%$ attendance at lectures to qualify to write examinations and that absenteeism from lectures, lateness to classes and engaging in different forms of examination malpractice are common in universities. Furthermore, the finding supports Akpochafo and Asiyai (2015) whose study revealed the different types of educational malpractice in tertiary institutions. 
The second finding has revealed that the grand mean of male lecturers is 3.00 while that of female lecturers is 3.12 , above the bench mark of 2.50. This has illustrated that there is no significant difference between male and female lecturers in their perception of the prevalence of malpractice among students. The implication is that both sexes have acknowledged the fact that undergraduates indulge in different forms of educational malpractice in Delta State University and that the rate is high. This finding is in line with Onoyase (2014) who observed some deviant behaviour among students of Delta State University and that they include paying colleagues to write assignments for them, inattentiveness in class and unwillingness of students to acquire textbooks and other reference materials. This result also supports the view of Aluede (2015) who opined that students resorts to "blocking", that is using money to get high and unmerited marks from lecturers in order to enhance their grade point. The plausible reason for this finding is that male and female lecturers alike, work in the same university environment where students indulge in these malpractices with impudence.

The last finding has shown that the grand mean score of junior lecturers (Assistant lecturers to lecturer 1) is 3.04 while that of senior lecturers (Senior lecturers to Professor) is 3.03. The mean score of lecturers, status notwithstanding is above 2.50. This has revealed that the lecturers have identified that educational malpractice is prevalent among their students. This finding agrees with the view of Bruno and Obidigbo (2012) who observed that the common forms of examination malpractice among undergraduates include coming to examination hall with small pieces of papers, giraffing or spying on their neighbours' work, whispering and impersonation. The reason for the finding is that the unethical behaviour of students is a reflection of what is happening in the larger society and junior and senior lecturers are witnessing this ugly situation.

\section{Conclusion}

The conclusion that can be drawn from this study is that there is high prevalence of educational malpractice among undergraduate students of Delta State University, Abraka. The negative behaviour exhibited by the students seems to reflect what is happening in the larger Nigerian society where indolence and dishonesty have become the order of the day.

\section{Recommendations}

Based on the findings, the following recommendations are made:

- University authorities should through the use of handbills and posters sensitize university students on the need to register their courses and the consequences of not registering.

- Penalties on non-registration of courses and absenteeism should be fully implemented.

- The ratio of students per lecturer (1:30) as stipulated by the National Universities Commission should be upheld for effective interaction.

- Counselling centres in various universities should organize seminar on regular basis to re-orientate students on core values of diligence, hard work and integrity.

\section{References}

Akaranga, S. I. \& Ongong, J. J. (2013). The Phenomenon of Examination, Malpractice: An example of Nairobi and Kenyatta University. Journal of Education and Practice, 4(18), 87 - 96.

Akpochafo, G. O. (2007). Unethical Behaviour Among Students of Tertiary Institutions. Being A paper Delivered at A One-Day Seminar organized by the Counselling Centre, Delta State University, Abraka, Delta State.

Akpochafo, G. O. \& Asiyai, R. I. (2015). Academic Staff and Students' Perception of Educational Malpractice in Tertiary Institutions in South - South Nigeria: Implication for Counselling. Delta Journal of Guidance and Counselling, 3(1), $37-54$.

Aluede, R.O.A. (2015). Emergent Issues and Educational Development in the Twenty-First Century. Being A keynote address presented at the 2015 International Conference and Workshop of the Faculty of Education. Delta State University, Abraka. Delta State.

Bruno, U.D.O. \& Obidigbo, G.C.E. (2012). The Counselling Implications of Examination Malpractice Among University Undergraduates. Research Journal in Organizational Psychology and Educational Studies, 1(3), 199-202

Ebenuwa-Okoh, E.E. (2009). Private School Ownership and Education Malpractice in Basic Education Programme. Being a paper delivered at a Seminar organized at Orerokpe by the Ministry of Education for private school owners. 
Faculty of Education, Delta State University, Abraka. (2016). Students Handbook. Abraka: Faculty of Education.

Machebe, C. H. \& Ifelunni, C. O. (2014). Influence of Parental Socio-Economic Status on Academic Achievement of Students in Selected Schools in Nigeria: A Case Study of Enugu State. Journal of Education and Practice, 5(2).

Onah, O.A. (2012). The Counselling Implication of Examination Malpractice. Nigerian Journal of' Science, Technology and Environmental Education, 3(1).

Onoyase, A. (2014). Factors Militating Against Students' Academic performance as Perceived by Undergraduates of Delta State University, Abraka. Journal of Education and Practice, 5(3), 94-99. 